\title{
PENGARUH PELAYANAN PUBLIK TERHADAP KEPUASAN MASYARAKAT DI KELURAHAN SUKAMAJU KECAMATAN SAKO KOTA PALEMBANG (STUDI KASUS PELAYANAN SURAT PENGANTAR NIKAH)
}

\author{
Oleh: \\ Saiton, S.Sos.,M.Si \\ Program Studi Administrasi Negara, STIA Satya Negara \\ e-Mail: saitonanton5@gmail.com
}

\begin{abstract}
In improving services, employees who are truly of high quality are needed so that interests that follow the basic rights of society can be carried out properly. Every organization, private or public, needs to build human resources that are professionally owned and have high competence. Highly competent employees will be the center of organizational excellence as well as support for organizational competitiveness in entering the era of globalization and facing the business environment and social conditions of society which are experiencing rapid changes.

The results of research and discussion, public services at the Sukamaju Urban Village office received a very good assessment (with a score of 81.75). However, of the 12 elements of service quality, there are some elements that are still deemed not fulfilling the wishes of the community. These elements are speed in service and certainty of service schedules. Both elements are in the good category, but the accumulative value is below the value of the other elements. this needs to be improved, so that in the future it can meet community expectations. So that good and satisfying service can really be felt by the community. The community satisfaction felt by the community when dealing with marriage cover letters at the Sukamaju Village office received a very good assessment (with a score of 88.25). Public Service has an effect on Community Satisfaction, the value obtained states that there is a positive influence and between Public Service on satisfaction (79.2\%). The results obtained state that if the service is improved, then the community satisfaction will also increase.
\end{abstract}

Keywords: public service, community satisfaction

\section{PENDAHULUAN}

Otonomi daerah tahun 2004, memberikan kewenangan yang luas kepada daerah untuk mengurus dan memenuhi kebutuhannya sendiri. Daerah juga diberikan kewenangan untuk memberikan kemajuan dan meningkatkan kesehjahteraan masyarakat. UndangUndang Republik Indonesia No 32 tahun 2005 Pasal 2 tentang Pemerintahan Daerah mengamanatkan otonomi luas kepada daerah untuk mempercepat kesehjahteraan masyarakat melalui peningkatan pelayanan, pemberdayaan dan peran serta masyarakat.

Menyediakan pelayanan publik yang baik adalah tugas Negara melalui Pemerintah. Pemenuhan kebutuhan publik diartikan sebagai pemenuhan hak-hak sipil warga negara. Tugas dan kewajiban ini dilakukan melalui aparat pemerintah dari tingkat paling atas sampai paling bawah seperti RW dan RT. Sebagai kewajiban, 
maka sudah semestinya setiap aparat pemerintah memberikan pelayanan publik yang terbaik.

Masyarakat setiap waktu selalu menuntut pelayanan publik yang berkualitas dari birokrat, meskipun tuntutan tersebut sering tidak sesuai dengan harapan karena secara empiris pelayanan publik yang terjadi selama ini masih bercirikan berbelit-belit, lambat, mahal, dan melelahkan. Kecenderungan ini dikarenakan masyarakat masih diposisikan sebagai pihak yang melayani bukan yang dilayani. Oleh karena itu, pada dasarnya dibutuhkan reformasi pelayanan publik dengan mengembalikan dan mendudukkan pelayan dan melayani kepada pengertian sesungguhnya. Hal

inilah yang memicu munculnya gerakan reformasi birokrasi. Menurut Sinambela, dkk (2006:25) reformasi adalah perubahan dimana kedalamannya terbatas dan melibatkan seluruh masyarakat.

Salah satu hal utama dalam agenda reformasi birokrasi adalah perubahan sudut pandang penyelenggara layanan publik, dari dilayani menjadi melayani, peningkatan disiplin kerja, peningkatan mutu pelayanan, dll. Sehingga dapat tercipta kesehjahteraan bagi seluruh masyarakat dan memberikan kepuasan bagi masyarakat. Namun reformasi birokrasi tidak akan berjalan jika tidak didukung dengan perubahan dari dalam birokrasi itu sendiri. Berupa perubahan pola pikir pegawai pemerintahan, peningkatan kemampuan dan meningkatkan kinerja pelayanan.

Berdasarkan Undang-undang No 25

Tahun 2009 Tentang Pelayanan Publik. Penyelenggaraan pelayanan publik yang baik harus berasaskan :

a. Kepentingan Umum. Yaitu Pemberian pelayanan tidak boleh mengutamakan kepentingan pribadi atau golongan b. Kepastian Hukum. Yaitu Jaminan terwujudnya hak dan kewajiban dalam penyelenggaraan pelayanan.

c. Kesamaan Hak. Yaitu Pemberian pelayanan tidak membedakan suku, ras, agama, golongan, gender, dan status ekonomi.

d. Keseimbangan Hak Dan Kewajiban. Yaitu Pemenuhan hak harus sebanding dengan kewajiban yang harus dilaksanakan, baik oleh pemberi maupun penerima pelayanan

e. Keprofesionalan. Yaitu Pelaksana pelayanan harus memiliki kompetensi yang sesuai dengan bidang tugas

f. Partisipatif. Yaitu Peningkatan peran serta masyarakat dalam penyelenggaraan pelayanan dengan memperhatikan aspirasi, kebutuhan, dan harapan masyarakat

g. Persamaan Perlakuan/Tidak Diskriminatif. Yaitu Setiap warga negara berhak memperoleh pelayanan yang adil.

h. Keterbukaan. Yaitu setiap penerima pelayanan dapat dengan mudah mengakses dan memperoleh informasi mengenai pelayanan yang diinginkan

i. Akuntabilitas. Yaitu Proses penyelenggaraan pelayanan harus dapat dipertanggungjawabkan sesuai dengan ketentuan peraturan perundangundangan.

j. Fasilitas Dan Perlakuan Khusus Bagi Kelompok Rentan. Yaitu Pemberian kemudahan terhadap kelompok rentan sehingga tercipta keadilan dalam pelayanan.

k. Ketepatan Waktu. Yaitu Penyelesaian setiap jenis pelayanan dilakukan tepat waktu sesuai dengan standar pelayanan.

1. Kecepatan, Kemudahan, dan Keterjangkauan. Yaitu Setiap jenis pelayanan dilakukan secara cepat, mudah, dan terjangkau. 
Dalam meningkatkan pelayanan dibutuhkan pegawai yang benar-benar berkualitas sehingga kepentingankepentingan yang mengikuti hak-hak dasar masyarakat dapat terlaksana dengan baik dan benar. Setiap organisasi, private atau publik perlu membangun sumber daya manusia yang dimiliki secara profesional dan memiliki kompetensi yang tinggi. Pegawai yang berkompetensi tinggi akan menjadi pusat keunggulan organisasi sekaligus sebagai pendukung daya saing organisasi dalam memasuki era globalisasi dan menghadapi lingkungan usaha serta kondisi sosial masyarakat yang mengalami perubahan begitu cepat.

\section{LANDASAN TEORI}

\subsection{Pelayanan Publik}

Pelayanan publik oleh aparatur pemerintah dewasa ini masih banyak dijumpai kelemahan sehingga belum dapat memenuhi kualitas yang diharapkan masyarakat. Hal ini ditandai dengan masih adanya berbagai keluhan masyarakat yang disampaikan melalui media massa, sehingga dapat menimbulkan citra yang kurang baik terhadap aparatur pemerintah. Mengingat fungsi utama pemerintah adalah melayani masyarakat maka pemerintah perlu terus berupaya meningkatkan kualitas pelayanan.

Pelayanan publik adalah segala kegiatan pelayanan yang dilaksanakan oleh penyelenggara pelayanan publik sebagai upaya pemenuhan kebutuhan penerima pelayanan, maupun dalam rangka pelaksanaan ketentuan peraturan perundang-undangan. Pelayanan publik merupakan suatu komponen penting bagi pemerintah dalam membentuk suatu pelayanan yang baik, prima dan memuaskan.

Dalam kamus besar bahasa Indonesia (2008:781) dijelaskan pelayanan sebagai hal, cara, atau hasil pekerjaan melayani. Sedangkan melayani adalah menyuguhi (orang) dengan makanan atau minuman, menyediakan keperluan orang, mengiyakan menerima, menggunakan. Sementara itu, istilah publik berasal dari bahasa Inggris Public yang berarti umum, masyarakat, dan Negara. Inu dkk yang diangkat oleh Sinambela, dkk (2006:5) mendefinisikan publik adalah sejumlah manusia yang memiliki kebersamaan berpikir, perasaan, harapan sikap dan tindakan yang benar dan baik berdasarkan nilai-nilai dan norma yang merasa memilliki. Oleh karana itu, pelayanan publik didefinisikan sebagai setiap kegiatan yang dilakukan pemerintah terhadap sejumlah manusia yang memiliki setiap kegiatan yang menguntungkan dalam suatu kumpulan atau kesatuan, dan menawarkan kepuasan meskipun hasilnya tidak terikat pada suatu produk secara fisik.

Berdasarkan Permenpan RB No 14 Tahun 2017 Tentang Survei Penyusunan Indeks Kepuasan Masyarakat Unit Peneyelengara Pelayanan Publik. Kepuasan pelayanan adalah hasil pendapat dan penilaian masyarakat terhadap kinerja pelayanan yang diberikan oleh aparatur penyelenggara pelayanan publik.

Dari pendapat-pendapat diatas. Maka dapat disimpulkan bahwa pelayanan publik adalah pemenuhan keinginan dan kebutuhan masyarakat oleh penyelenggara Negara.

Para ahli memberikan pengertian kualitas dari cara pandang mereka masingmasing. Beberapa pengertian kualitas yang sering dikemukakan, antara lain :

1. Menurut Joseph M. Juran dalam Moenir (2010:21) kualitas adalah "fitness for use" yang berarti kesesuaian dengan pengguna.

2. Menurut Philip B. Crosby dalam Moenir (2010:23) kualitas adalah "conformance to reguerements" 
yang berarti kesesuaian terhadap persyaratan.

3. Menurut Edwards W. Derming dalam Moenir (2010:45) kualitas adalah "satisfy custumers needs" yang berarti memuaskan kebutuhan dari konsumen. Deming juga mempelopori gerakan Plan, Do, Check, Action (PDCA).

4. Menurut Armand V. Feigenbaum dalam Moenir (2010:27) kualitas adalah tanggung jawab dari semua orang dalam perusahaan.

5. Menurut Gaspersz dala Moenir (2010:25) kualitas adalah segala sesuatu yang mampu memenuhi keinginan atau kebutuhan pelanggan (Meeting The Needs of Custumers). Kualitas terdiri dari sejumlah keistimewaan produk, baik keistimewaan langsung, maupun keistimewaan atraktif yang memenuhi keinginan pelanggan dan memberikan kepuasan atas pengguna produk. Kualitas terdiri dari segala sesuatu yang bebas dari kekurangan atau kerusakan.

Pengertian kualitas secara konvensional menggambar karakteristik langsung suatu produk seperti :

1. Kinerja (Performance)

2. Keandalan (Reliability)

3. Mudah dalam penggunaaan (Ease of use)

4. Estetika (Esthetics)

Dari beberapa pengertian kualitas dapat dipandang secara lebih luas, yaitu tidak hanya sekedar hasil dari suatu produk, tetapi juga meliputi proses, lingkungan dan manusia dalam rangka menghasilkan suatu produk atau jasa. Bahkan pengertian kualitas secara modern adalah turunnya variabelitas proses dalam pembuatan suatu produk, artinya bahwa bila variasi dalam proses menurun, maka kualitas dari suatu produk meningkat.
Selanjutnya Garvin (dalam Yamit, 2004:56) kemudian mengembangkan dimensi kualitas ke dalam delapan dimensi yang dapat digunakan sebagai dasar perencanaan strategis terutama perusahaan yang menghasilkan barang/jasa. Kedelapan dimensi tersebut adalah sebagai berikut :

1. Performance (kinerja), yaitu karakteristik pokok dari produk inti.

2. Features, yaitu karakteristik pelengkap atau tambahan.

3. Realibility (kehandalan), yaitu kemungkinan tingkat kegagalan pemakaian.

4. Conformance (kesesuaian), sejauhmana karakter desain dan operasi produk/jasa memenuhi standar-standar yang telah ditetapkan sebelumnya.

5. Durability (daya tahan), yaitu mengukur berapa lama suatu umur teknis maupun umur ekonomis suatu produk.

6. Serviceability (pelayanan), yaitu mudah untuk diperbaiki yang meliputi kecepatan, kompetensi, kenyamanan, kemudahan dalam pemiliharaan dan penanganan keluhan yang memuaskan.

7. Esthetics (estetika), yaitu menyangkut corak, rasa, dan daya tarik.

8. Percived Quality, yaitu menyangkut citra atau reputasi produk serta tanggung jawab perusahaan terhadap produk.

Sedangkan pelayanan, terdapat beberapa pengertian yang sering dikemukakan oleh para ahli maupun yang terdapat didalam peraturan perundangundangan, antara lain :
1. Menurut Lukman (2009:89) pelayanan adalah suatu urutan kegiatan yang terjadi dalam interaksi langsung dengan orang- 
orang atau mesin secara fisik dan menyediakan kepuasan konsumen.

2. Menurut Davidow dalam Nursyabani (2006:51) pelayanan adalah hal-hal yang jika diterapkan terhadap suatu produk akan meningkatkan daya atau nilai terhadap pelanggan (service is those thing which when added to a product, increase its utility of value to the customer).

3. Menurut Kasmir (2005:78) pelayanan adalah tindakan atau perbuatan seseorang atau organisasi untuk memberikan kepuasan kepada pelanggan. Pelayanan merupakan suatu kegiatan atau urutan kegiatan yang terjadi dalam interaksi langsung antara seseorang dengan orang lain atau mesin secara fisik dan menyediakan kepuasan pelanggan.

4. Peraturan Menteri Pendayagunaan Apartur Negara dan Reformasi Birokrasi RI No. 14 Tahun 2017 Tentang Survei Kepuasan Masyarakat, bahwa dalam rangka pembinaan aparatur negara yang diarahkan untuk peningkatan kinerja pelayanan publik diperlukan adanya upaya mendorong kinerja dalam rangka percepatan reformasi unit pelayanan publik sebagai sarana evaluasi kemajuan peningkatan kinerja pelayanan publik.

5. Pasal 5 UU No. 24 Tahun 2009 Tentang Ruang lingkup pelayanan publik menurut Undang-Undang Pelayanan Publik meliputi pelayanan barang publik dan jasa publik serta pelayanan administratif yang diatur dalam peraturan perundang-undangan. Dalam ruang lingkup tsb, termasuk pendidikan, pengajaran, pekerjaan dan usaha, tempat tinggal, komunikasi dan informasi, lingkungan hidup, kesehatan, jaminan sosial, energi, perbankan, perhubungan, sumber daya alam, pariwisata, dan sektor strategis lainnya.

Berdasarkan pengertian kualitas dan pelayanan diatas, maka dapat pahami bahwa Kepuasan Masyarakat(service quality) merupakan tingkat keunggulan yang diharapkan dan pengendalian atas tingkat keunggulan tersebut untuk memenuhi keinginan pelanggan. (Zeithaml dalam Ratminto \& Atik Winarsih. 2007:45)

\subsubsection{Faktor-faktor mempengaruhi Pelayanan}

Gronroos dalam Ratminto \& Atik Winarsih. (2007:67) mengemukakan bahwa terdapat lima faktor yang mempengaruhi kualitas pelayanan, yaitu :

1. Menjaga dan memperhatikan, bahwa pelanggan akan merasakan pegawai/karyawan dan sistem opersional yang ada dapat menyelesaikan problem mereka.

2. Spontanitas, dimana pegawai/karyawan menunjukkan keinginan untuk menyelesaikan masalah pelanggan.

3. Penyelesaian masalah, pegawai/karyawan yang berhubungan langsung dengan pelanggan harus memiliki kemampuan untuk menjalankan tugas berdasarkan standar yang ada, termasuk pelatihan yang diberikan untuk dapat memberikan pelayanan yang lebih baik.

4. Perbaikan, apabila terjadi hal-hal yang tidak diinginkan harus mempunyai personal yang dapat menyiapkan usaha-usaha khusus untuk mengatasi kondisi tersebut. 
5. Evaluasi kinerja, evaluasi kinerja atau penilaian kinerja dikatakan penting mengingat melalui penilaian kinerja dapat diketahui seberapa tepat pegawai telah menjalankan fungsinya termasuk dalam menciptakan kualitas pelayanan yang baik.

\subsubsection{Indikator Pelayanan Publik}

Berdasarkan Undang-undang No 25 Tahun 2009 Tentang Pelayanan Publik. Penyelenggaraan pelayanan publik yang baik harus berasaskan :

a. Kepentingan Umum. Yaitu Pemberian pelayanan tidak boleh mengutamakan kepentingan pribadi atau golongan

b. Kepastian Hukum. Yaitu Jaminan terwujudnya hak dan kewajiban dalam penyelenggaraan pelayanan.

c. Kesamaan Hak. Yaitu Pemberian pelayanan tidak membedakan suku, ras, agama, golongan, gender, dan status ekonomi.

d. Keseimbangan Hak Dan Kewajiban. Yaitu Pemenuhan hak harus sebanding dengan kewajiban yang harus dilaksanakan, baik oleh pemberi maupun penerima pelayanan

e. Keprofesionalan. Yaitu Pelaksana pelayanan harus memiliki kompetensi yang sesuai dengan bidang tugas

f. Partisipatif. Yaitu Peningkatan peran serta masyarakat dalam penyelenggaraan pelayanan dengan memperhatikan aspirasi, kebutuhan, dan harapan masyarakat

g. Persamaan Perlakuan/Tidak Diskriminatif. Yaitu Setiap warga negara berhak memperoleh pelayanan yang adil.

h. Keterbukaan. Yaitu setiap penerima pelayanan dapat dengan mudah mengakses dan memperoleh informasi mengenai pelayanan yang diinginkan

i. Akuntabilitas. Yaitu Proses penyelenggaraan pelayanan harus dapat dipertanggungjawabkan sesuai dengan ketentuan peraturan perundang-undangan.

j. Fasilitas Dan Perlakuan Khusus Bagi Kelompok Rentan. Yaitu Pemberian kemudahan terhadap kelompok rentan sehingga tercipta keadilan dalam pelayanan.

k. Ketepatan Waktu. Yaitu Penyelesaian setiap jenis pelayanan dilakukan tepat waktu sesuai dengan standar pelayanan.

1. Kecepatan, Kemudahan, dan Keterjangkauan. Yaitu Setiap jenis pelayanan dilakukan secara cepat, mudah, dan terjangkau.

\subsubsection{Kriteria Pelayanan Yang Memuaskan}

Kembali pada persoalan hak mendapatkan pelayanan, dapat dinyatakan bahwa hak ini berlaku kepada siapapun, baik ia anggota organisasi yang berkewajiban melayani atau orang luar bukan organisasi itu. Sebagai pihak yang ingin memperoleh pelayanan yang baik dan memuaskan, maka perwujudan pelayanan yang didambakan ialah :

a. Adanya kemudahan dalam pengurusan kepentingan dengan pelayanan yang cepat dalam arti tanpa hambatan yang kadang kala dib uat-buat.

b. Memperoleh pelayanan yang wajar tanpa gerutu, sindiran atau utaian kata lain semacam itu yang nadanya mengarah pada permintaan sesuatu, baik dengan alasan dinas (pembelian kertas, ganti ongkos foto kopi dll) 
c. Mendapatkan perlakuan yang sama tanpa dibeda-bedakan dalam memperoleh kepentingan yang sama.

d. Pelayanan yang jujur dan terus terang, artinya apabila ada hambatan karena suatu masalah hendaknya diberitahukan, agar masyarakat tidak menunggu untuk alas an yang tidak pasti.

Adapun tata cara untuk Pengurusan Surat Nikah yang harus dipersiapkan antara lain :

1. Pernyataan Orang Tua wali

2. KK Asli dan Photo Copy

3. Surat cerai asli dari pengadilan agama dan photo copy 1 lembar (bagi yang cerai hidup )

4. Photo copy surat kematian/Akte kematian suami/istri (bagi yang cerai mati)

5. Photo Copy SPPT dan Tanda lunas PBB tahun terakhir.

6. Map Warna Hijau

Salah satu hal utama dalam agenda Reformasi birokrasi adalah perubahan sudut pandang penyelenggara layanan publik, dari dilayani menjadi melayani, peningkatan disiplin kerja, peningkatan mutu pelayanan, dll.

Adapun berdasarkan Permenpan RB No 14 Tahun 2017 Tentang Survei Penyusunan Indeks Kepuasan Masyarakat Unit Peneyelengara Pelayanan Publik. Pelayanan yang memuaskan harus memenuhi 9 indikator. Indikator-indikator tersebut antara lain :
a. Persyaratan Pelayanan, yaitu persyaratan teknis dan administratif
b. Sistem, Mekanisme, Prosedur
c. waktu pelayanan, sesuai dengan ketentuan yang telah ditetapkan.
d. Biaya pelayanan,
e. Produk Spesifikasi dan Jenis Pelayanan
f. Kompetensi Pelaksana
g. Perilaku Pelaksana
h. Penanganan Pengaduan, Saran dan Masukan
i. Sarana dan Prasarana.

\subsubsection{Pengertian Pegawai}

Aparatur adalah sumber daya manusia yang berkerja sesuai dengan kemampuannya, di bidangnya masingmasing sesuai dengan ketentuan yang ada. Pegawai Negeri Sipil sebagai aparatur negara Pengertian Pegawai Negeri Sipil didalam masyarakat yang selalu berkembang, manusia senantiasa mempunyai kedudukan yang makin penting, meskipun Negara Indonesia menuju kepada masyarakat yang berorientasi kerja, yang memandang kerja adalah sesuatu yang mulia, tidaklah berarti mengabaikan manusia yang melaksanakan kerja tersebut.

Demikian juga halnya dalam suatu organisasi, unsur manusia sangat menentukan sekali karena berjalan tidaknya suatu organisasi kearah pencapaian tujuan yang ditentukan tergantung kepada kemampuan manusia untuk menggerakkan organisasi tersebut ke arah yang telah ditetapkan. Manusia yang terlibat dalam organisasi ini disebut juga pegawai.

$$
\text { Menurut Widjaja (2006:113) }
$$

Pegawai adalah merupakan tenaga kerja manusia jasmaniah maupun rohaniah (mental dan pikiran) yang senantiasa dibutuhkan dan oleh karena itu menjadi salah satu modal pokok dalam usaha kerja sama untuk mencapai tujuan tertentu (organisasi)

Berdasarkan definisi diatas dapat diketahui bahwa pegawai merupakan modal pokok dalm suatu organisasi, baik organisasi pemerintah maupun organisasi swasta. Berhasil tidaknya suatu organisasi mencapai tujuannya tergantung dari pegawai yang memimpin dalam melaksanakan tugas-tugas yang ada dalam 
organisasi tersebut. Pegawai yang telah memberikan tenaga dan pikirannnya dalam melaksanakan tugas ataupun pekerjaan, baik organisasi pemerintah maupun organisasi swasta akan mendapat imbalan sebagai balas jasa atas pekerjaan yang telah dilakukan.

Selanjutnya

Moeheriono(2010:215) memberikan definisi pegawai sebagai berikut Pekerja atau worker adalah, "Mereka yang secara langsung digerakkan oleh seorang manajer untuk bertindak sebagai pelaksana yang akan menyelenggarakan pekerjaan sehingga menghasilkan karya-karya yang diharapkan dalam usaha pencapaian tujuan organisasi yang telah ditetapkan.

Dari definisi tersebut dapat ditarik suatu kesimpulan bahwa pegawai sebagai tenaga kerja atau yang menyelenggarakan pekerjaan perlu digerakkan sehingga mereka mempunyai keterampilan dan kemampuan dalam bekerja yang pada akhirnya akan dapat menghasilkan karyakarya yang bermanfaat untuk tercapainya tujuan organisasi. Karena tanpa kemampuan dan keterampilan. Pegawai sebagai pelaksana pekerjaan maka alat-alat dalam organisasi tersebut akan merupakan benda mati dan waktu yang dipergunakan akan terbuang dengan percuma sehingga pekerjaan tidak efektif.

\subsubsection{Pegawai Pemerintah}

Ada dua ada dua pengertian pegawai negeri menurut Undang-Undang Pokok Kepegawaian No.43 Tahun 1999 Tentang Perubahan UU No.8 Tahun 1974 Tentang Pokok-Pokok Kepegawaian yaitu:

1. Pegawai negeri adalah unsur aparatur negara, abdi negara, dan abdi masyarakat yang dengan kesetiaan dan ketaatan kepada Pancasila dan Undang-Undang Dasar 1945, negara dan pemerintah, menyelenggarakan tugas pemerintahan dan pembangunan.

2. Pegawai negeri adalah mereka yang telah memenuhi syarat-syarat yang ditentukan dalam peraturan perundang-undangan yang berlaku, diangkat oleh pejabat yang berwenang dan diserahi tugas dalam sesuatu jabatan negeri atau diserahi tugas negara lainnya yang ditetapkan berdasarkan sesuatu peraturan perundang-undangan dan digaji menurut peraturan perundang-undangan yang berlaku. Pegawai Negeri terdiri dari Pegawai Negeri Sipil (PNS) dan anggota Tentara Nasional Indonesia dan Anggota Kepolisian Negara Republik Indonesia. Hanya dibatasi pada Pegawai Negeri Sipil, maka selanjutnya hanya dijelaskan mengenai perincian Pegawai Negeri Sipil. Pasal 2 Undang-Undang Republik Indonesia Nomor 43 Tahun 1999 Tentang Perubahan Atas Undang-Undang Nomor 8 Tahun 1974 Tentang Pokok-Pokok Kepegawaian, yang menjelaskan Pegawai Negeri sipil terdiri dari:

1. Pegawai negeri sipil pusat

2. Pegawai negeri sipil daerah

3. Pegawai negeri sipil lain yang ditetapkan dengan peraturan pemerintah

\section{Metode Penelitian}

Metode penelitian ini menggunakan metode penelitian deskriftif kuantitatif dan menggunakan instrument penelitian kuisioner. Berdasarkan sifatnya, maka penelitian ini merupakan penelitian yang bersifat asosiatif. Yaitu suatu penelitian yang menggambarkan pengaruh Pengaruh Pelayanan Publik Terhadap Kepuasan Masyarakat pada kantor Kelurahan Sukamaju Kecamatan Sako Kota Palembang 


\section{HASIL PENELITIAN DAN \\ PEMBAHASAN}

\section{A. HASIL PENELITIAN}

Berdasarkan data yang didapat peneliti, jumlah populasi yang sesuai dengan kriteria penelitian ini adalah sebesar 35 jiwa. Namun karena keterbatasan waktu, tenaga, dan biaya. Maka diambil sampel dengan syarat pernah melakukan pengurusan surat pengantar pernikahan. Pengambilan responden dilakukan secara

Tabel 11

Jumlah Responden Berdasarkan Jenis Kelamin insidental sampling, besaran jumlah responden diambil dengan rumus yang telah ditetapkan dalam Permenpan RB No 14 Tahun 2017 adalah sebanyak 32 orang. Rincian responden untuk Kepuasan Masyarakatyang diambil berdasarkan jenis kelamin, perkerjaan, dan jenis pelayanan yang dilakukan adalah sebagai berikut:

a. Responden Berdasarkan Jenis Kelamin

\begin{tabular}{|c|l|c|c|}
\hline No & \multicolumn{1}{|c|}{ Jenis Kelamin } & Jumlah (orang) & Persentase (\%) \\
\hline 1 & Laki-laki & 25 orang & $78,1 \%$ \\
\hline 2 & Perempuan & 7 0rang & $21,9 \%$ \\
\hline & & 32 orang & $100 \%$ \\
\hline
\end{tabular}

Sumber: Pengolahan Data Primer

Dari pengolahan data yang didasari oleh kuesioner yang disebarkan pada masyarakat, maka didapat jumlah laki-laki lebih banyak yang mengurus keperluannya pada kantor Kelurahan Sukamaju.

b. Responden berdasarkan pekerjaan

Tabel 12

Jumlah Responden Berdasarkan Jenis Kelamin

\begin{tabular}{|c|l|c|c|}
\hline No & \multicolumn{1}{|c|}{ Jenis Kelamin } & Jumlah (orang) & Persentase (\%) \\
\hline 1 & Karyawan Swasta & 15 Orang & 46,88 \\
\hline 2 & Wiraswasta & 13 Orang & 40,62 \\
\hline 3 & PNS Jumlah & 4 Orang & 12,50 \\
\hline & \multicolumn{2}{r}{ 32 orang } & $100 \%$ \\
\hline
\end{tabular}

Sumber: Pengolahan Data Primer

Dari pengolahan data yang didasari oleh kuesioner yang disebarkan pada masyarakat, maka didapat bahwa 15 orang masyarakat yang datang adalah karyawan swasta, 13 orang wiraswasta, dan 4 orang PNS

\section{Pelayanan Publik}

Untuk memperoleh pendapat masyarakat tentang Pelayanan Publik oleh pegawai Kelurahan Sukamaju Kota Palembang, maka disebar kuesioner yang berisi 12 unsur pertanyaan tentang pelayanan. Kuesioner tersebut disebar kepada 32 responden dan setelah dilakukan pengolahan data menggunakan rumus SKM.

Maka diperoleh nilai kualitas pelayanansebagai berikut: 
Tabel 13

NRR Kualitas pelayanan

\begin{tabular}{|l|l|c|c|c|}
\hline \multicolumn{1}{|c|}{ Indikator } & \multicolumn{1}{|c|}{ Kuisioner } & $\begin{array}{c}\text { Total } \\
\text { Skor }\end{array}$ & $\begin{array}{c}\text { Rata-Rata } \\
\text { (NRR unsur) }\end{array}$ & $\begin{array}{c}\text { Konversi } \\
\text { Nilai }\end{array}$ \\
\hline Kepentingan Umum & Pertanyaan 1 & 86 & 2,68 & BAIK \\
\hline Kepastian Hukum & Pertanyaan 2 & 89 & 2,78 & BAIK \\
\hline Kesamaan Hak & Pertanyaan 3 & 91 & 2,84 & BAIK \\
\hline Keseimbangan Hak Dan Kewajiban & Pertanyaan 4 & 77 & 2,40 & BAIK \\
\hline Keprofesionalan & Pertanyaan 5 & 94 & 2,93 & BAIK \\
\hline Partisipatif Perlakuan/Tidak & Pertanyaan 6 & 91 & 2.84 & BAIK \\
\hline $\begin{array}{l}\text { Persamaan } \\
\text { Diskriminatif }\end{array}$ & Pertanyaan 7 & 71 & 2,21 & BAIK \\
\hline Keterbukaan 8 & 76 & 2,37 & BAIK \\
\hline Akuntabilitas Perlakuan Khusus & Pertanyaan 9 & 87 & 2,71 & BAIK \\
\hline $\begin{array}{l}\text { Fasilitas Dan } \\
\text { Bagi Kelompok Rentan }\end{array}$ & Pertanyaan 11 & 68 & 2,53 & BAIK \\
\hline Ketepatan Waktu & Pertanyaan 12 & 74 & 2,31 & BAIK \\
\hline Kecepatan
\end{tabular}

Sumber: Pengolahan Data Primer

Berdasarkan tabel rata-rata nilai yang diberikan oleh masyarakat terhadap pelayanan Publik saat pengurusan surat pengantar pernikahan pada kantor Kelurahan Sukamaju Kota Palembang diatas. Maka, diperoleh kesimpulan bahwa dari 12 unsur bidang pelayanan berdasar Undang-Undang No 25 Tahun 2009, sudah dirasa memuaskan/ baik oleh masyarakat.
1. Indeks
Kepuasan

MasyarakatMasyarakat
Setelah didapatkan hasil rata-rata setiap unsur pelayanan Publik, selanjutnya berdasarakan permenpan RB nomor 14 Tahun 2017 bahwa indeks per unsur adalah jumlah rata-rata nilai (NRR) setiap unsur. Sedangkan nilai komposit (gabungan) untuk setiap unsur, merupakan hasil dari NRR perunsur X nilai penimbang. Adapun nilai penimbang diperoleh dari:

Tabel 14

NRR Tertimbang Perunsur

\begin{tabular}{|l|c|c|c|}
\hline \multicolumn{1}{|c|}{ Indikator } & Rata-Rata & Penimbang & $\begin{array}{c}\text { NRR per } \\
\text { unsur }\end{array}$ \\
\hline Kepentingan Umum & 2,68 & 0.11 & 0,29 \\
\hline Kepastian Hukum & 2,78 & 0.11 & 0,30 \\
\hline Kesamaan Hak & 2,84 & 0.11 & 0,31 \\
\hline Keseimbangan Hak Dan Kewajiban & 2,40 & 0.11 & 0,26 \\
\hline Keprofesionalan & 2,93 & 0.11 & 0,32 \\
\hline Partisipatif & 2.84 & 0.11 & 0,31 \\
\hline Persamaan Perlakuan & 2,21 & 0.11 & 0,24 \\
\hline Keterbukaan & 2,37 & 0.11 & 0,26 \\
\hline Akuntabilitas & 2,71 & 0.11 & 0,30 \\
\hline
\end{tabular}




\begin{tabular}{|l|c|c|c|}
\hline $\begin{array}{l}\text { Fasilitas Dan Perlakuan Khusus Bagi } \\
\text { Kelompok Rentan }\end{array}$ & 2,53 & 0.11 & 0,27 \\
\hline Ketepatan Waktu & 2,12 & 0.11 & 0,23 \\
\hline Kecepatan & 2,31 & 0.11 & 0,25 \\
\hline \multicolumn{3}{|l}{ Total nilai/SKM pelayanan } & 3,27 \\
\hline
\end{tabular}

Selanjutunya, dari hasil pengolahan dengan mengalikan NRR perunsur dengan bobot tertimbang. Didapat hasil NRR tertimbang perunsur adalah 3,27. Total NRR tertimbang perunsur akan menjadi nilai indeks kualitas pelayanan. Dalam Peremnan RB Nomor 14 ahun 2017 dijelaskan, untuk mempermudah interprestasi terhadap penilaian. Maka hasil penilaian harus dikalikan nilai dasar yaitu 25.

Maka didapatkan nilai, yaitu:

\section{3,27 X $25=81,75$}

Nilai tersebut kemudian dikonversi dengan Tabel 3.3 Nilai Persepsi, Interval SKM, Interval Konversi SKM, Mutu Pelayanan dan Mutu Pelayanan pada Bab III. Maka didapatkan bahwa:

Pelayanan Publik dirasakan oleh masyarakat pada saat mengurusi surat pengantar pernikahan di kantor Kelurahan Sukamaju Kota Palembang berada pada kategori
A atau dengan predikat Sangat Baik.

\section{Kepuasan Masyarakat}

Untuk memperoleh pendapat masyarakat tentang kepuasan masyarkat oleh pegawai Kelurahan Sukamaju Kota Palembang, maka disebar kuesioner yang berisi 9 unsur pertanyaan tentang pelayanan. Kuesioner tersebut disebar kepada 32 responden dan setelah dilakukan pengolahan data menggunakan rumus SKM.

Maka diperoleh nilai kualitas pelayanansebagai berikut:

Tabel 15

NRR Kualitas pelayanan

\begin{tabular}{|l|l|c|c|c|}
\hline \multicolumn{1}{|c|}{ Indikator } & \multicolumn{1}{|c|}{ Kuisioner } & $\begin{array}{c}\text { Total } \\
\text { Skor }\end{array}$ & $\begin{array}{c}\text { Rata-Rata } \\
\text { (NRR unsur) }\end{array}$ & $\begin{array}{c}\text { Konversi } \\
\text { Nilai }\end{array}$ \\
\hline Persyaratan Pelayanan & Pertanyaan 1 & 116 & 3,62 & BAIK \\
\hline Sistem, Mekanisme, Prosedur & Pertanyaan 2 & 116 & 3,62 & BAIK \\
\hline waktu pelayanan, & Pertanyaan 3 & 116 & 3,62 & BAIK \\
\hline Biaya pelayanan & Pertanyaan 4 & 120 & 3,75 & BAIK \\
\hline $\begin{array}{l}\text { Produk Spesifikasi dan Jenis } \\
\text { Pelayanan }\end{array}$ & Pertanyaan 5 & 114 & 3,56 & BAIK \\
\hline Kompetensi Pelaksana & Pertanyaan 6 & 115 & 3,59 & BAIK \\
\hline Perilaku Pelaksana & Pertanyaan 7 & 122 & 3,81 & BAIK \\
\hline $\begin{array}{l}\text { Penanganan Pengaduan, Saran } \\
\text { dan Masukan }\end{array}$ & Pertanyaan 8 & 113 & 3,53 & BAIK \\
\hline
\end{tabular}




\begin{tabular}{|c|c|c|c|}
\hline Sarana dan Prasarana & 113 & 3,53 & BAIK \\
\hline \multicolumn{4}{|l|}{ Sumber: Pengolahan Data Primer } \\
\hline $\begin{array}{l}\text { Berdasarkan tabel rata-rata nilai } \\
\text { yang diberikan oleh masyarakat terhadap } \\
\text { pelayanan Publik saat pengurusan surat } \\
\text { pengantar pernikahan pada kantor }\end{array}$ & \multicolumn{3}{|c|}{$\begin{array}{l}\text { untuk setiap unsur, merupakan hasil dari } \\
\text { NRR perunsur X nilai penimbang. Adapun } \\
\text { nilai penimbang diperoleh dari: }\end{array}$} \\
\hline $\begin{array}{l}\text { Kelurahan Sukamaju Kota Palembang } \\
\text { diatas. Maka, diperoleh kesimpulan bahwa }\end{array}$ & \multicolumn{3}{|c|}{$\begin{array}{l}\text { Maka didapat NRR tertimbang per } \\
\text { unsur }\end{array}$} \\
\hline
\end{tabular}

dari 9 unsur bidang pelayanan berdasar Undang-Undang No 25 Tahun 2009, sudah dirasa memuaskan/ baik oleh masyarakat.

2. Indeks Kepuasan Masyarakat

Setelah didapatkan hasil rata-rata setiap unsur pelayanan Publik, selanjutnya berdasarakan permenpan RB nomor 14 Tahun 2017 bahwa indeks per unsur adalah jumlah rata-rata nilai (NRR) setiap unsur. Sedangkan nilai komposit (gabungan)

Tabel 16

NRR Tertimbang Perunsur

\begin{tabular}{|l|c|c|c|}
\hline \multicolumn{1}{|c|}{ Indikator } & Rata-Rata & Penimbang & NRR per unsur \\
\hline Persyaratan Pelayanan & 3,62 & 0.11 & 0,39 \\
\hline Sistem, Mekanisme, Prosedur & 3,62 & 0.11 & 0,39 \\
\hline waktu pelayanan, & 3,62 & 0.11 & 0,39 \\
\hline Biaya pelayanan & 3,75 & 0.11 & 0,41 \\
\hline Produk Spesifikasi dan Jenis Pelayanan & 3,56 & 0.11 & 0,39 \\
\hline Kompetensi Pelaksana & 3,59 & 0.11 & 0,39 \\
\hline Perilaku Pelaksana & 3,81 & 0.11 & 0,41 \\
\hline $\begin{array}{l}\text { Penanganan Pengaduan, Saran dan } \\
\text { Masukan }\end{array}$ & 3,53 & 0.11 & 0,38 \\
\hline Sarana dan Prasarana Total nilai/SKM pelayanan & 0.11 & 0,38 \\
\hline \multicolumn{2}{|l|}{3,53} & & 3,53 \\
\hline
\end{tabular}

Sumber: Pengolahan Data Primer

Selanjutunya, dari hasil pengolahan dengan mengalikan NRR perunsur dengan bobot tertimbang. Didapat hasil NRR tertimbang perunsur adalah 3,53. Total NRR tertimbang perunsur akan menjadi nilai indeks kualitas pelayanan. Dalam Peremnpan RB Nomor 14 ahun 2017 dijelaskan, untuk mempermudah interprestasi terhadap penilaian. Maka hasil penilaian harus dikalikan nilai dasar yaitu 25 .

Maka didapatkan nilai, yaitu:

$$
3,53 \times 25=88,25
$$

Nilai tersebut kemudian dikonversi dengan Tabel Nilai Persepsi, Interval SKM, Interval Konversi SKM, Mutu Pelayanan dan Mutu Pelayanan pada Bab III. Maka didapatkan bahwa: 
Kepuasan Masyarakat yang dirasakan oleh masyarakat pada saat mengurusi Surat Pengantar Pernikahan dikantor Kelurahan Sukamaju Kota Palembang berada pada kategori $\boldsymbol{A}$ atau dengan predikat Sangat Baik

\section{Pengaruh Pelayanan Publik Terhadap Kepuasan Masyarakat}

Berdasarkan hasil kuesioner yang diberikan kepada responden, maka tahap selanjutnya adalah menentukan pengaruh dari variabel $\mathrm{X}$ terhadap variabel $\mathrm{Y}$. rumus yang digunakan adalah regresi sederhana. Setelah dilakukan penghitungan dengan bantuan program Statistical Package for the Social Sciences (SPSS) Statistik versi 20.0 maka diperoleh hasil sebagai berikut:

1. Pengaruh Pelayanan Publik terhadap Kepuasan Masayarakat Berikut merupakan bagian utama untuk melihat pengaruh Pelayanan Publik terhadap kualitas pelayanan:

Tabel 17

Pengaruh Variabel X Terhadap Y

Coefficients $^{\mathrm{a}}$

\begin{tabular}{|c|c|c|c|c|c|c|}
\hline \multirow{2}{*}{\multicolumn{2}{|c|}{ Model }} & \multicolumn{2}{|c|}{ Unstandardized Coefficients } & \multirow{2}{*}{$\begin{array}{c}\text { Standardized } \\
\text { Coefficients }\end{array}$} & \multirow[t]{2}{*}{$\mathrm{t}$} & \multirow[t]{2}{*}{ Sig. } \\
\hline & & B & Std. Error & & & \\
\hline \multirow{2}{*}{1} & (Constant) & 8.119 & 3.523 & & 2.305 & .028 \\
\hline & Pelayanan Publik & .797 & .114 & .786 & 6.972 & .000 \\
\hline
\end{tabular}

a. Dependent Variable: Kepuasaan Masyarakat

Sumber: pengolahan Data Primer Dgn IBM SPSS Statistik versi 20.0

Tabel diatas merupakan keluaran persamaan regresi sederhana. Persamaan regresi sederhana ini adalah:

$$
\mathrm{Y}=\mathrm{a}+\mathrm{bX}
$$

Berdasarkan tabel coofisient diatas maka didapat persamaan regresi sederhananya adalah:

$$
\mathrm{Y}=8.119+0,797 \mathrm{X}
$$

Penjelasan dari persamaan regresi diatas adalah:

1. Nilai 8,119 artinya jika tidak ada peningkatan Pelayanan Publik $\mathrm{X}=0$, maka Kepuasan Masyarakatsebesar 8,119 .
2. 0,797 artinya jika terjadi penambahan/peningkatan

Pelayanan Publik maka tingkat Kepuasan Masyarakatakan bertambah/meningkat sebesar 0,797 .

3. Persentase Pengaruh (Koefisien Determinasi)

Berdasarkan tabel berikut maka dapat terlihat tingkat persentase pengaruh variabel $\mathrm{X}$ terhadap variabel $\mathrm{Y}$

Tabel 18

Persentase Pengaruh

Model Summary

\begin{tabular}{|l|c|r|r|r|}
\hline Model & R & R Square & Adjusted R Square & Std. Error of the Estimate \\
\hline 1 & $.786^{\mathrm{a}}$ & .618 & .606 & .911 \\
\hline
\end{tabular}

a. Predictors: (Constant), PELYANAN PUBLIK 
Bagian ini menunjukkan besarnya koofesien determinasi yang berfungsi untuk memprediksi besarnya persentase pengaruh variabel bebas terhadap variabel terikat. Dari tabel diatas dapat terlihat tabel $\mathrm{R}$ sebesar 0, 786 yang artinya jika dikuadrankan dengan hasil korelasi yang dikalikan 100\%. Maka didapat bahwa pengaruh Pelayanan Publik terhadap Kepuasan Masyarakatadalah 78,6\% Sementara sisanya $(100-78.6=21,4 \%)$ dipengaruhi variabel lain.

2. Kelayakan regresi dalam memprediksi variabel Y (Uji F) Penggunanaan regresi sederhana harus dibuktikan apakah sudah layak digunakan untuk memprediksi keberadaan variabel Y. Jika terbukti tidak layak, maka rumus regresi sederhana tidak bisa digunakan. Atau harus menggunakan variabel lain

Berikut adalah tabel yang menunjukkan kelayakan penggunaan regresi dalam memprediksi nilai variabel $\mathrm{Y}$ dengan bantuan program IBM SPSS $\begin{array}{llll}\text { Statistik } & \text { versi } & 20.0 \quad \text { : }\end{array}$

Tabel 19

Prediksi Kelayakan

ANOVA

\begin{tabular}{|rl|r|r|r|r|r|}
\hline \multicolumn{1}{|l|}{ Model } & \multicolumn{1}{c|}{$\begin{array}{c}\text { Sum of } \\
\text { Squares }\end{array}$} & \multicolumn{1}{c|}{ df } & Mean Square & F & \multicolumn{1}{c|}{ Sig. } \\
\hline \multirow{3}{*}{1} & Regression & 40.331 & 1 & 40.331 & 48.614 & $.000^{\mathrm{b}}$ \\
& Residual & 24.888 & 30 & .830 & & \\
& Total & 65.219 & 31 & & & \\
\hline
\end{tabular}

a. Dependent Variable: KEPUASAAN MASYARAKAT

b. Predictors: (Constant), PELYANAN PUBLIK

Besarnya angka signifikansi yang baik adalah harus lebih kecil dari 0,005. Atau dapat diartikan standar eror sebesar $5 \%$.

Tabel anova diatas menunjukkan angka $\mathrm{F}$ sebesar 48,614 dengan tingkat signifikansi 0,000 . Karena angka signifikansi $0,000<0,005$ (lebih kecil). Maka dinyatakan model regresi sudah layak digunakan dalam memprediksi variabel Y.

\section{Uji Hipotesis}

Uji hipotesis digunakan untuk melihat kekuatan pengaruh variabel
Pelayanan Publik terhadap kualitas pelayanan, hipotesis merupakan jawaban atas rumusan masalah yang telah ditetapkan pada BAB I. Hipotesis dalam penelitian ini hanya untuk rumusan masalah berbentuk asosiatif. sedangkan untuk rumusan masalah berbentuk deskriftif tidak dirumuskan.

Uji hipotesis menggunakan rumus korelasi product moment. Berdasarkan pengolahan data menggunakan program SPSS versi 20.0,maka diperoleh hasil sebagai berikut: 
Tabel 20

Korelasi

Correlations

\begin{tabular}{|c|c|c|c|}
\hline & & Variabel_X & Variabel_Y \\
\hline \multirow{4}{*}{ Variabel_X } & Pearson Correlation & 1 & $.786^{* * *}$ \\
\hline & Sig. (2-tailed) & & .000 \\
\hline & $\mathrm{N}$ & 32 & 32 \\
\hline & Pearson Correlation & $.786^{* *}$ & 1 \\
\hline \multirow[t]{2}{*}{ Variabel_Y } & Sig. (2-tailed) & .000 & \\
\hline & $\mathrm{N}$ & 32 & 32 \\
\hline
\end{tabular}

**. Correlation is significant at the 0.01 level (2-tailed).

Sumber: pengolahan Data Primer Dgn SPSS versi 20,0

Berdasarkan tabel 20 tersebut maka koofisien korelasi yang ditemukan sebesar 0,786 dan jika dinterpretasikan dengan tabel 1. Maka tingkat kekuatan pengaruh variabel Pelayanan Publik terhadap Kepuasan Masyarakatberada pada kategori Kuat.

Tahap selanjutnya adalah melihat tingkat positif/negatif pengaruh variabel Pelayanan Publik terhadap kualitas pelayanan.

$$
\begin{gathered}
\mathbf{r}_{\text {hit }}>\mathbf{r}_{\text {tabel }} \\
\mathbf{0 , 7 8 6}>0,349
\end{gathered}
$$

\section{Uji Validitas dan Reliabilitas Instrumen}

Validitas dan reliabilitas suatu penelitian sangat bergantung pada validitas dan reabilitas instrument penelitian tersebut. Validitas instrument adalah tingkat ketepatan instrument yang digunakan untuk mengukur apa yang hendak diukur dalam suatu penelitian, sementara reliabilitas instrument adalah
Berdasarkan perhitungan yang ditunjukkan diatas, maka dinyatakan $r$ hitung lebih besar dari $r$ tabel. Maka dapat dinyatakan hipotesis (Ho) yang menyatakan tidak terdapat pengaruh ditolak dan hipotesis alternatife (Ha) diterima. Nilai 0,786 yang didapat adalah positif yang artinya koofisien tersebut dapat digeneralisirkan atau dapat berlaku pada keseluruhan populasi dimana sampel 32 orang tersebut diambil.

digunakan untuk mengkur berkali-kali dan menghasilkan data yang sama (konsisten)

a. Indikator Pelayanan Publik

Pengujian validitas dan reliabilitas dilakukan terhadap 32 responden. Uji validitas menggunakan rumus korelasi pearson dan uji reliabilitas menggunakan rumus cronbach alpa. Uji validitas dan reliabilitas indikator kompetensi pegawai dapat dilihat pada tabel berikut:

Tabel 21

\begin{tabular}{|c|c|c|c|c|c|c|}
\hline \multirow[b]{2}{*}{ Indikator } & \multicolumn{3}{|c|}{ Validitas } & \multicolumn{2}{|c|}{ Reliabilitas } & \multirow[b]{2}{*}{ Keterangan } \\
\hline & $\begin{array}{c}\text { Pearson } \\
\text { correlation }\end{array}$ & $\begin{array}{c}\mathrm{R} \\
\text { kritis }\end{array}$ & Sig & $\begin{array}{l}\text { Cronbach alfa if } \\
\text { item dileted }\end{array}$ & $\begin{array}{c}\mathbf{R} \\
\text { kritis }\end{array}$ & \\
\hline U1 & 0,760 & 0,30 & 0,000 & 0,880 & 0,60 & Valid\&Relialibel \\
\hline $\mathrm{U} 2$ & 0,761 & 0,30 & 0,000 & 0,879 & 0,60 & Valid\&Relialibel \\
\hline
\end{tabular}

Uji Validitas Reliabilitas Pelayanan Publik 


\begin{tabular}{|c|c|c|c|c|c|c|}
\hline U3 & 0,707 & 0,30 & 0,000 & 0,884 & 0,60 & Valid\&Relialibel \\
\hline U4 & 0,838 & 0,30 & 0,000 & 0,870 & 0,60 & Valid\& Relialibel \\
\hline U5 & 0,840 & 0,30 & 0,000 & 0,870 & 0,60 & Valid\&Relialibel \\
\hline U6 & 0,889 & 0,30 & 0,000 & 0,862 & 0,60 & Valid\&Relialibel \\
\hline U7 & 0,769 & 0,30 & 0,000 & 0,881 & 0,60 & Valid\&Relialibel \\
\hline U8 & 0,475 & 0,30 & 0,000 & 0,901 & 0,60 & Valid\&Relialibel \\
\hline U9 & 0,819 & 0,30 & 0,000 & 0,920 & 0,60 & Valid\&Relialibel \\
\hline U10 & 0,754 & 0,30 & 0,000 & 0,923 & 0,60 & Valid\&Relialibel \\
\hline U11 & 0,562 & 0,30 & 0,001 & 0,930 & 0,60 & Valid\&Relialibel \\
\hline U12 & 0,625 & 0,30 & 0,000 & 0,928 & 0,60 & Valid\&Relialibel \\
\hline
\end{tabular}

Sumber: Pengolahan Data Primer

Berdasarkan tabel 5.10 hasil uji validitas reliabiliatas dapat diketahui bahwa semua instrumen/indikator variabel pelayanan publik dinyatakan valid karena dari hasil korelasi antara hasil jawaban responden pada tiap instrumen/indikator dengan skor total di dapat hasil yang signifikan, yaitu lebih besar dari nilai $r$ kritis (korelasi $>0,30$ ) dan dengan nilai signifikan dibawah nilai 0,005 (sig. < 0,005)

Nilai cronbachalphasemua variabel di atas nilai $r$ kritis yaitu 0,60 , dengan demikian instrumen/indikator yang digunakan variabel pelayanan publik terbukti reliabel atau dapat dipercaya sebagai alat ukur variabel, yaitu apabila dilakukan pengukuran ulang maka data yang didapat akan konsisten dari waktu ke waktu

b. Uji Validitas dan Reliabilitas Indikator Kepuasan Masyarakat.

Uji validitas dan reabilitas digunakan untuk melihat kelayakan pertanyaan yang digunakan dalam penyusunan kuisioner.Pengujian validitas dan reabilitas dilakukan terhadap 32 responden. Uji validitas dalam penelitian ini menggunakan rumus korelasi pearson dan uji reliabilitas menggunakan rumus cronbach alpha. Berdasar rumus korelasi person, unsur yang dianggap valid harus lebih besar dari $r$ kritis sebesar 0,30 dengan tingkat signifikan lebih kecil dari 0,005. Dan berdasar rumus cronbach alpha, unsur yang dianggap relialibel harus lebih besar dari r kritis yaitu 0,60 .

Uji validitas dan reliabilitas indikator Kepuasan Masyarakat dapat dilihat pada tabel berikut:

Tabel 20

Uji Validitas Dan Reliabilitas Kepuasan Masyarakat

\begin{tabular}{|c|c|c|c|c|c|c|}
\hline \multirow{2}{*}{ Indikator } & \multicolumn{3}{|c|}{ Validitas } & \multicolumn{2}{c|}{ Reliabilitas } & \multirow{2}{*}{ Keterangan } \\
\cline { 2 - 6 } & $\begin{array}{c}\text { Pearson } \\
\text { correlation }\end{array}$ & $\begin{array}{c}\mathbf{R} \\
\text { kritis }\end{array}$ & Sig & $\begin{array}{c}\text { Cronbach alfa if } \\
\text { item dileted }\end{array}$ & $\begin{array}{c}\mathbf{R} \\
\text { kritis }\end{array}$ & \\
\hline U1 & 0,749 & 0,30 & 0,000 & 0,922 & 0,60 & Valid\&Relialibel \\
\hline U2 & 0,637 & 0,30 & 0,000 & 0,926 & 0,60 & Valid\&Relialibel \\
\hline U3 & 0,570 & 0,30 & 0,001 & 0,928 & 0,60 & Valid\&Relialibel \\
\hline U4 & 0,761 & 0,30 & 0,000 & 0,922 & 0,60 & Valid\& Relialibel \\
\hline U5 & 0,871 & 0,30 & 0,000 & 0,917 & 0,60 & Valid\&Relialibel \\
\hline U6 & 0.612 & 0,30 & 0,000 & 0,927 & 0,60 & Valid\&Relialibel \\
\hline U7 & 0,821 & 0,30 & 0,000 & 0,919 & 0,60 & Valid\&Relialibel \\
\hline U8 & 0,763 & 0,30 & 0,000 & 0,922 & 0,60 & Valid\&Relialibel \\
\hline
\end{tabular}




\begin{tabular}{|l|c|c|c|c|c|c|}
\hline U9 & 0,848 & 0,30 & 0,000 & 0,919 & 0,60 & Valid\&Relialibel \\
\hline
\end{tabular}
Sumber: Pengolahan Data Primer

Semua instrumen / indikator variabel kepuasan masyarakat dinyatakan valid karena dari hasil korelasi antara hasil jawaban responden pada tiap instrumen/indikator dengan skor total di dapat hasil yang signifikan, yaitu lebih besar dari nilai $r$ kritis (korelasi $>0,30$ ) dan dengan nilai signifikan dibawah nilai 0,05 (sig. $<0,005$ )

Semua nilai variabel kepuasan pelayanan di atas lebih besar dari nilai $r$ kritis $(0,60)$, dengan demikian instrumen/indikator yang digunakan terbukti reliabel atau dapat dipercaya sebagai alat ukur variabel kepuasan masyarakat.

\section{PEMBAHASAN}

\section{A. Pelayanan Publik}

$\begin{array}{lrr}\text { Nilai } & \text { SKM yang didapat } \\ \text { menunjukkan } & \text { secara } & \text { keseluruhan } \\ \text { masyarakat merasa bahwa Pelayanan }\end{array}$ Publik yang diberikan oleh pegawai kantor Kelurahan Sukamaju berada pada kategori baik. Dari 12 unsur yang dipakai masyarakat memberi penilaian semua unsur tersebut sudah terpenuhi.

Unsur yang pertama yaitu prosedur pelayanan dan kesesuaiannya dengan yang dijalankan atau dilaksanakan dalam memberikan pelayanan. Prosedur yang telah ditetapkan dan dilaksanakan tidak menyimpang dari peraturan yang ada dan dibuat oleh pemerintah Kota Palembang, sehingga saat masyarakat melakukan pelayanan tidak terjadi kebingungan. Apalagi peraturan tersebut telah tersosialisasi dengan baik ketengah masyarakat.

Unsur pelayanan yang baik dan memuaskan selanjutnya adalah mengenai keamanan dan kenyamanan tempat pelayanan. Pegawai Kelurahan Sukamaju Kota Palembang telah menyediakan tempat yang aman dan nyaman bagi masyarakat. Sehingga masyarakat merasa puas dan memberi penilaian baik.

Namun dari 12 unsur kualitas pelayanan, terdapat beberapa unsur yang masih dirasa belum memenuhi keinginan masyarakat. Unsur tersebut adalah kecepatan dalam pelayanan dan kepastian jadwal pelayanan. Kedua unsur tersebut berada dalam kategori baik, namun nilai akumulatifnya berada dibawah nilai unsur lain. hal ini perlu mendapatkan perbaikan, sehingga untuk masa selanjutnya dapat memenuhi harapan masyarakat. Sehingga pelayanan yang baik dan memuaskan benar-benar dapat dirasakan oleh masyarakat.

Berdasarkan Undang-undang No 25 Tahun 2009 Tentang Pelayanan Publik. Penyelenggaraan pelayanan publik yang baik harus berasaskan antara lain yaitu ketepatan waktu. yaitu penyelesaian setiap jenis pelayanan dilakukan tepat waktu sesuai dengan standar pelayanan dan kecepatan, kemudahan, dan keterjangkauan. yaitu setiap jenis pelayanan dilakukan secara cepat, mudah, dan terjangkau.

Keputusan Menteri Pendayagunaan Aparatur Negara Nomor 25 Tahun 2014 Tentang Pedoman Umum Penyusunan Indeks Kepuasan Masyarakat Unit Pelayanan Instansi Pemerintah. Juga menyebutkan bahwa unsur pelayanan yang baik dan memuaskan harus memenuhi 9 indikator. Indikator-indikator tersebut antara lain Kecepatan pelayanan, yaitu target waktu pelayanan dapat diselesaikan dalam waktu yang telah ditentukan oleh unit penyelenggara pelayanan dan Kepastian jadwal pelayanan, yaitu pelaksanaan waktu pelayanan, sesuai dengan ketentuan yang telah ditetapkan.

Dari peraturan pemerintah tersebut, jelas terlihat bahwa kecepatan dan 
kepastian jadwal pelayanan merupakan hal penting yang dapat menciptakan pelayanan yang baik dan memuaskan bagi masyarakat. Jika unsur-unsur tersebut dapat diperbaiki dan dibenahi dan ditambah peningkatan dari unsure-unsur yang lain. Maka hal tersebut dapat memberikan dan menumbuhkan sikap patuh dan hormat masyarakat terhadap instansi pemerintahan Kelurahan Sukamaju Kota Palembang.

\section{B. Kepuasan Masyarakat}

Hasil pengolahan dengan mengalikan NRR perunsur dengan bobot tertimbang. Didapat hasil NRR tertimbang perunsur adalah 3,53. Total NRR tertimbang perunsur akan menjadi nilai indeks kualitas pelayanan. Dalam Peremnpan RB Nomor 14 ahun 2017 dijelaskan, untuk mempermudah interprestasi terhadap penilaian. Maka hasil penilaian harus dikalikan nilai dasar yaitu 25. Didapatkan nilai, yaitu: 3,53 X $25=88,25$

Nilai tersebut kemudian dikonversi dengan Tabel Nilai Persepsi, Interval SKM, Interval Konversi SKM, Mutu Pelayanan dan Mutu Pelayanan pada Bab III. Maka didapatkan bahwa Kepuasan Masyarakat yang dirasakan oleh masyarakat pada saat mengurusi Surat Pengantar Pernikahan dikantor Kelurahan Sukamaju Kota Palembang berada pada kategori A atau dengan predikat Sangat Baik. Apa yang terjadi sudah sangat sesuai dengan toeri yang berdasarkan Permenpan RB No 14 Tahun 2017 Tentang Survei Penyusunan Indeks Kepuasan Masyarakat Unit Peneyelengara Pelayanan Publik. Pelayanan yang memuaskan harus memenuhi 9 indikator. Indikator-indikator tersebut antara lain :

a. Persyaratan Pelayanan, yaitu persyaratan teknis dan administratif yang diperlukan untuk mendapatkan pelayanan sesuai dengan jenis pelayanannya. b. Sistem, Mekanisme, Prosedur

c. waktu pelayanan, sesuai dengan ketentuan yang telah ditetapkan.

d. Biaya pelayanan, yaitu keterjangkauan masyarakat terhadap besarnya biaya yang ditetapkan oleh unit pelayanan

e. Produk Spesifikasi dan Jenis Pelayanan

f. Kompetensi Pelaksana

g. Perilaku Pelaksana

h. Penanganan Pengaduan, Saran dan Masukan

i. Sarana dan Prasarana

\section{Pengaruh Pelayanan Publik Terhadap Kepuasan Masyarakat}

Pelayanan Publik memberikan pengaruh yang positif terhadap kualitas pelayanan. Hasil dari kuisioner yang disebar terhadap 32 responden yang dipilih secara insidental sampling, dan diuji menggunakan rumus-rumus yang diolah dengan SPSS statistik 20.0. Menunjukkan bahwa ada pengaruh yang positif.

Berdasarkan uji persentase dalam regresi sederhana, didapati hasil 79,2 \% Pelayanan Publik dapat mempengaruhi kualitas pelayanan. Dari hasil uji regresi sederhana juga didapat hasil bahwa jika pelayanan publik meningkat maka Kepuasan Masyarakat juga meningkat. Hal ini juga didukung hasil dari uji t, hasil yang positif menandakan bahwa Pelayanan Publik bisa memberikan Kepuasan Masyarakat kepada masyarakat Kelurahan Sukamaju saat mengurusi keperluannya.

Hasil yang positif tersebut harus dipertahankan dan ditingkatkan, agar pada masa selanjutnya Pelayanan Publik Kelurahan Sukamaju benar-benar mampu memberikan rasa puas pada masyarakat yang mengurusi keperluaanya, agar dapat tercipta suatu birokrasi yang sesuai dengan amanat undang-undang dan semangat reformasi birokrasi. Namun jika melihat 
persentase pengaruh yang didasarkan uji hipotesis, uji kelayakan dan uji koofesien determinasi yang menunjukkan bahwa pengaruh Pelayanan Publik terhadap Kepuasan Masyarakathanya sebesar 79,2 \% atau dalam kategori kuat. Maka Pelayanan Publik yang ada belumlah sesuai harapan dan perlu ditingkatkan.

Terdapat beberapa indikator Pelayanan Publik, Permenpan RB No 14 Tahun 2017 Tentang Survei Penyusunan Indeks Kepuasan Masyarakat Unit Peneyelengara Pelayanan Publik. Pelayanan yang memuaskan harus memenuhi 9 indikator. Indikator-indikator tersebut antara lain :

1. Persyaratan Pelayanan, yaitu persyaratan teknis dan administratif yang diperlukan untuk mendapatkan pelayanan sesuai dengan jenis pelayanannya.

2. Sistem, Mekanisme, Prosedur

3. waktu pelayanan, sesuai dengan ketentuan yang telah ditetapkan.

4. Biaya pelayanan, yaitu keterjangkauan masyarakat terhadap besarnya biaya yang ditetapkan oleh unit pelayanan

5. Produk Spesifikasi dan Jenis Pelayanan

6. Kompetensi Pelaksana

7. Perilaku Pelaksana

8. Penanganan Pengaduan, Saran dan Masukan

9. Sarana dan Prasarana.

\section{SIMPULAN}

Berdasarkan hasil penelitian dan pembahasan, maka penulis membuat simpulan sebagai berikut:

1. Pelayanan Publik pada kantor Kelurahan Sukamaju memperoleh penilaian sangat baik (dengan nilai 81,75). Namun dari 12 unsur kualitas pelayanan, terdapat beberapa unsur yang masih dirasa belum memenuhi keinginan masyarakat. Unsur tersebut adalah kecepatan dalam pelayanan dan kepastian jadwal pelayanan. Kedua unsur tersebut berada dalam kategori baik, namun nilai akumulatifnya berada dibawah nilai unsur lain. hal ini perlu mendapatkan perbaikan, sehingga untuk masa selanjutnya dapat memenuhi harapan masyarakat. Sehingga pelayanan yang baik dan memuaskan benar-benar dapat dirasakan oleh masyarakat.

2. Kepuasan Masyarakat yang dirasakan masyarakat saat mengurusi urusan surat pengantar pernikahan pada kantor Kelurahan Sukamaju memperoleh penilaian sangat baik (dengan nilai 88,25). Petugas telah memberikan penjelasan yang baik tentang prosedur pelayanan, disiplin dalam berkerja, bertanggung jawab terhadap perkerjaan, menyediakan tempat yang aman dan nyaman, serta tarif pelayanan tidak menyimpang dari peraturan,

3. Pelayanan Publik berpengaruh terhadap Kepuasan Masyarakat, nilai yang didapat menyatakan bahwa ada pengaruh positif dan antara Pelayanan Publik terhadap kepuasan (79,2\%). Hasil yang didapat menyatakan bahwa jika pelayanan ditingkatkan, maka Kepuasan Masyarakat juga akan ikut meningkat. Pengaruh positif tersebut didapat karena adanya kemauan petugas dalam memberikan pelayanan dan mampu mengontrol diri. Sehingga dalam melayani masyarakat petugas mampu memaksimalkan semua unsur yang ada dalam teori kualitas pelayanan. 
DAFTAR PUSTAKA

Aryani, Dwi dan Febrina Rosinta . 2010.

Pengaruh Kualitas Layanan

terhadap Kepuasan Pelanggan

dalam Membentuk Loyalitas

Pelanggan. Jurnal Ilmu

Administrasi dan Organisasi

Volume 17, Nomor 2 (online)

(http://scholar.google.co.id/scholar

_url?url=http://www.ijil.ui.ac.id/ind

ex.php/jbb/article/download/632/61

$7 \& \mathrm{hl}=\mathrm{id} \& \mathrm{sa}=\mathrm{X} \&$ scisig=AAGBfm 1

16OQNelD3ttlNyHXyHFkf7L1GP

A\&nossl=1\&oi=scholarr, diakses 7

November 2018)

Indriani, Sugeng Rusmiwari, Agung Suprojo. 2017. Pengaruh Pelayanan Publik Terhadap Kepuasan Masyarakat: Studi Kasus Izin Produksi Pangan Industri Rumah Tangga Di Kantor Badan Penanaman Modal Kota Batu Jurnal ilmu sosial dan politik Vol 6, No $2 . \quad$ (Online) (https://publikasi.unitri.ac.id/index. php/fisip/article/view/525. Diakses 7 Noveber 2018)

Dendawijaya, Lukman. 2009. Manajemen Perbankan. Jakarta: Ghalia Indonesia

Kasmir. 2005. Manajemen Perbankan: Etika Costumer Services. Jakarta: PT. Raja Grafindo

Moenir, H.A.S. 2010. Manajemen Pelayanan Umum Di Indonesia. Jakarta : Bumi Aksara.

Muchlis. 2015. Pengaruh Kepuasan MasyarakatPublik Terhadap

Kepuasan Masyarakat Di Kecamatan Wonosari (Studi Pelayanan e-KTP di Kecamatan Wonosari)

(Online) (https://www.academia.edu/138833

39/PENGARUH_KUALITAS_PE

LAYANAN_PUBLIK?auto=downl oad. Diakses 7 November 2018)

Prasetyo, Bambang \& Lina Miftahul Jannah. 2005. Metode Penelitian Kuantitatif : Teori dan Aplikasi. Jakarta : PT. Rajagrafindo Persada.

Purnama, Nursyabani. 2006. Manajemen Kualitas:Perspektif Global. Yogyakarta: Ekonisia

Ratminto \& Atik Winarsih. 2007. Manajemen Pelayanan. Jakarta: Pustaka Pelajar

Sinambela, Lijan Poltak, dkk. 2006. Reformasi Pelayanan Publik. Jakarta : PT. Bumi Aksara.

Sugiyono. 2014. Metodelogi Penelitian Kuantitatif Kualitatif dan $R \& D$. Bandung : Alfabeta.

Widjaja, A.W. 2006. Administrasi Kepegawaian. Jakarta : Rajawali

Yamit, Zulian. 2004. Manajemen Kualitas

Produk \& Jasa. Yogyakarta: Ekonesia

\section{Sumber dari Undang-undang}

Peraturan Menteri Pendayagunaan Aparatur Negara Dan Reformasi Birokrasi Nomor 14 Tahun 2017 Tentang Pedoman Penyusunan Survei Kepuasan Masyarakat Unit Pelayanan Instansi Pemerintah. 2017. Jakarta : Menteri Pendayagunaan Aparatur Negara Dan Reformasi Birokrasi

Undang-Undang No 25 Tahun 2009 Tentang Pelayanan Publik. 2009. Jakarta : DPR RI dan Presiden RI 